\title{
Day Times Gram Per Milliliter Per Gram
}

National Cancer Institute

\section{Source}

National Cancer Institute. Day Times Gram Per Milliliter Per Gram. NCI Thesaurus. Code C112246.

Days times grams per milliliter, divided by grams. 